\title{
Bossa nova songs translated into Italian: translation process analysis based on $\mathrm{Au}-$ bert's translation modalities
}

Tatiane Marques Calloni*

\section{Introduction}

Studies conducted by scholars such as Şebnem Susam-Sarajeva (2008), Peter Low $(2005,2008)$, and Johan Franzon (2008) have shed light on the subject of song translation. These studies are quite recent, even though professionals and enthusiasts have been translating songs for a long time. Susam-Sarajeva (2008) identifies three main reasons why song translation has not received much attention. First, she mentions the social role of music, its influence on individuals, and the lack of research focused on these important topics. Secondly, she states that song translation is not usually considered as translation proper due to the constant occurrence of adaptation and version. Thirdly, the researcher's background may limit the studies focused on song translation as it involves different disciplines. Therefore, it is necessary to use a multidisciplinary approach in order to avoid theses constraints (Susam-Sarajeva 2008, p. 189).

Despite being a challenging task, song texts are constantly being translated mainly because it allows the listener to understand the meaning of the song. The analysis of the translation process may reveal valuable information regarding culture and creativity and may also demonstrate the relevance of this topic to the fields of translation, music, linguistics, and culture. As said by Susam-Sarajeva (2008), “Music goes hand in hand with ethnic, cultural, linguistic, gendered and national identities and representations" (p. 194).

${ }^{*}$ Universidade de São Paulo (USP) 
This article aims to analyze the translation process of six Brazilian songs composed by the poet and musician Vinicius de Moraes. We based the analysis on the translation modalities proposed by Francis Henrik Aubert (1998). The songs were translated into Italian by Sergio Bardotti for the album titled La Vita, Amico, è l'Arte dell'Incontro (2005). It is important to mention that Bardotti did not describe the procedures used to translate the songs.

\title{
Bossa nova meets the world
}

The coexistence of different cultures influenced Brazilian music significantly, as noted by Tatit (2004). According to the author, not only classical and sacred European compositions were heard during the period of colonization but also popular songs, which created a strong bond between voice and guitar. Enslaved Africans, in turn, brought the African rhythm to Brazil. Deprived of their land and freedom, they tried to preserve their culture through religious rituals and festive dances, all accompanied by African drums. This cultural fusion resulted in the genre known as samba (Tatit 2004, pp. 21-22).

Many composers developed and enriched samba. João Gilberto, for instance, was known for his innovative way of singing and playing guitar. His "sing as you speak" technique transformed samba into bossa nova. Tom Jobim, in turn, innovated and refined the harmony structure of his songs in order to adapt it to the new way of singing. Tatit (2004) continues:

\begin{abstract}
Pode-se dizer que até a bossa nova o Brasil correu atrás de si próprio, em busca da decantação do que lhe era essencial, do que o distinguia como nação e, consequentemente, como sonoridade autêntica. Nesse anseio de triagem, chegou ao samba, forma complexa que atinge o auge de elaboração no período bossa-nova [It can be said that up to bossa nova, Brazil chased itself trying to preserve what was essential, what distinguished it as a nation and, consequently, as an authentic sound. This desire for selection led to samba, a complex form that reached its peak in the bossa nova period]. (p. 214)
\end{abstract}

Bossa nova became known in Europe thanks to the United States, which appreciated the new Brazilian music genre, as described by Campos (1993, p. 104). To be better accepted, bossa nova undergone some changes as 
it was too refined and discreet at a time when dance and performance prevailed (Campos, 1993, pp. 105-106).

Naves (2001, p. 25) mentions famous North American musicians who recorded bossa nova songs, especially Frank Sinatra, whose voice made the song "Garota de Ipanema" well known throughout the world. The Brazilian music genre then spread to other countries.

\title{
Aspects of song translation
}

Language and culture strongly influence song translation. Languages are not only a means of communication but also a way of representing people's cultural identity. They contain structures, words, and concepts related to their own history, traditions, and knowledge. As indicated by Pajdzińska (2013):

\begin{abstract}
A language consolidates the cognitive experience of the community it serves, or more precisely, of the various generations and groups within the community, each of which may approach the same fragment of reality form a different viewpoint, following its own sentiments and needs. In consequence, the linguistic worldview that results is complex, multi-layered, heterogenic, and dynamic: it derives from continually occurring cognitive acts, whose effects accumulate, coexist, change, supplant, or are superimposed upon one another. (p. 44)
\end{abstract}

Regarding language structures and cultural information, Tagnin (2005) describes the concepts of conventionality and idiomaticity. The author states that conventionality depends on social interaction and requires the speaker to know the right time and way to say something. As an example, Tagnin (2005, p. 21) mentions the expression Merry Christmas, which is socially conventional. Idiomaticity, in turn, consists of expressions that do not have a transparent meaning because they do not correspond to the literal meaning of its words. For instance, the English idiom to kick the bucket means "to die" and does not mean to actually kick a bucket (Tagnin 2005, p. 22).

Songs usually reflect the culture in which they are embedded and popular songs, in particular, seem to allow more experimentation. These factors further complicate the already challenging task of translating, but there 
is another one, more important than any other, that influences song translation: the music structure. Both lyricists and translators must respect the melody and rhythm structures when writing or translating a song text, which explains why many translated songs tend to lose their original meaning completely or partially. According to Gritsenkoa and Aleshinskaya (2016), "Translation of song lyrics has never been about lexical precision. It aims to convey the message of a song in a different language by matching words and music, i.e., by integrating the verbal component of a song into its rhythm and melody" (p. 171).

Rhythm and melody must be adapted if the translator decides to remain as close to the literal meaning of the text as possible. In this case, the song will be a new composition based on the original one. The translator must be aware that song translation goes beyond the meaning of the source text and must consider many other important aspects. Franzon (2008) states that a song consists of music, lyrics, and performance, while the music itself consists of melody, harmony, and perceived sense. The author then continues defining a song:

\footnotetext{
A song can be defined as a piece of music and lyrics - in which one has been adapted to the other, or both to one another - designed for a singing performance. This third requisite is important for a functional view of song translation. (Franzon 2008, p. 376)
}

It will not always be possible to maintain the original meaning of the text if the main objective is to preserve the singability of a song. Low (2003, 2005) describes singability as the possibility of successfully singing a translated lyric with the same naturalness as the original song, respecting its melody and rhythm. This is one of the author's five proposed criteria in his approach named The Pentathlon Principle (Low 2003, 2005). The other four criteria are sense, naturalness, rhythm, and rhyme (Low, 2003, 2005).

Some verses from the album La Vita, Amico, è l'Arte dell'Incontro (2005), translated into Italian by Sergio Bardotti, had their meaning completely or partially changed to fit into the melody and rhythm of the songs. Despite the changes, Bardotti was able to preserve the general meaning of 
the source texts in all translations, as indicated in the following example consisting of two verses from the song "Rancho das Flores" and its translation into Italian:

Table 1: Source and Target Verses Comparison

\begin{tabular}{|l|l|}
\hline \multicolumn{1}{|c|}{ Source Verses } & \multicolumn{1}{c|}{ Target Verses } \\
\hline $\begin{array}{l}\text { Do grande jardim da existência das flo- } \\
\text { res }\end{array}$ & $\begin{array}{l}\text { Del grande giardino nel mondo dei } \\
\text { fiori }\end{array}$ \\
\hline Tão cheio de cores gentis & $C^{\prime}$ è chi soffre di vanità \\
\hline
\end{tabular}

The first translated verse had its meaning partially preserved, although it was necessary to make a small change regarding the lexical choice to better adapt the Italian version to the rhythm and melody. The second translated verse, however, has a completely different meaning from the source verse. These verses would not fit into the music structure if they were translated literally (e.g., Del grande giardino dell'esistenza dei fiori / Così pieno di colori gentili, which is more similar to the meaning conveyed by the source text).

\section{Aubert's translation modalities}

Aubert (1998a, 1998b) based his translation modalities on a model developed by Vinay and Darbelnet (1958) that measures the extent to which the target text resembles the source text through different degrees of proximity, from the most literal to the most adapted or altered. Aubert's model consists of thirteen translation modalities that represent different levels of translation. We describe below each modality, according to Aubert's definitions (1998a, 1998b).

Omission: this modality occurs when the translator omits part of the source text and its information from the target text.

Transcription: refers to textual elements equally represented in both source and target texts such as symbols, numbers, and elements that belong to a third language. 
Loan: the translator reproduces a segment of the source text ipsis litteris in the target text because there are no words or expressions in the target language that convey the same information contained in the source segment. As an example, Aubert (1998b, p. 136) mentions the English words outdoor and office boy as part of Brazilian Portuguese vocabulary.

Calque: like the previous one, this modality also represents words taken from the original text, but in this case, the translator modifies them graphically or morphologically to approach the target language.

Literal translation: translation is literal when each segment of the source text can be considered equivalent to the segments of the target text. For this to occur, the target text must have the same order and number of words, the same grammatical categories and must also have words considered equivalent to those of the source text. Aubert (1998b, p. 136) gives the following example: (1)Her (2)name (3)is (4)Maria (English) / (1)Seu (2)nome (3)é (4)Maria (Brazilian Portuguese).

Transposition: modality required if the previous conditions are not met. It means that the target text segment will be different from the source text segment, even if the translator succeeds in preserving the meaning. Aubert mentions cases in which two or more words become one, one word becomes two or more words, among other aspects. One of the examples given by Aubert (1998b, p. 137) is the translation of Kindergarten (one word in English) into Jardim de Infância (three words in Brazilian Portuguese).

Explicitation / Implicitation: languages have particular words, expressions, and concepts. Explicitation is applied when the translator must explain or complement these contents in the target text. The translator may opt to leave that segment implicit in the target text. As an example, Aubert (1998b, p. 137) mentions that it would be needless to say that Brasilia is the Federal Capital of Brazil in a translation into Brazilian Portuguese. Therefore, the translator could leave this information implicit in the target text. It might be necessary, however, to make this information explicit in texts translated into other languages.

Modulation: modality applied when a translated segment undergoes an apparent semantic change but still retains the general meaning of the 
source segment. Aubert (1998b, p. 138) gives the following example: It is very difficult (English) / Não é nada fácil (Brazilian Portuguese).

Adaptation: modality applied when the source text contains a particular worldview, which means that the segment will have no equivalent in the target language. In this case, the proposed solution is to choose a segment in the target language that is only partially equivalent to the meaning of the source segment but still meets the translation requirements, as indicated by Aubert (1998b, p. 138) in the following example: MA in Linguistics (English) / Mestrado em Letras (Brazilian Portuguese).

Intersemiotic translation: modality applied when the translator textually describes the symbols, signs, and figures from the source text.

Error: represents those cases in which the target text conveys a different meaning from the source text due to mistakes committed by the translator.

Correction: applied by the translator in the case of linguistic errors or wrong information in the source text, thus improving the target text.

Addition: modality applied when the translator adds segments and information in the target text that were not present in the source text.

The following table contains examples of each previously listed modality, taken from the six songs composed by Vinicius de Moraes and its translations. Bardotti did not offer any example of Transcription, Intersemiotic Translation, Error, or Correction in his translations. Therefore, these modalities will not be considered in this article.

Table 2: Examples of Translation Modalities

\begin{tabular}{|l|l|l|}
\hline $\begin{array}{l}\text { Translation Mo- } \\
\text { dality }\end{array}$ & \multicolumn{1}{|c|}{ Source Segment } & \multicolumn{1}{c|}{ Target Segment } \\
\hline Omission & A bênção, todos os grandes & Benedizione, grandi \\
\hline Loan & $\begin{array}{l}\text { Porque o samba nasceu lá } \\
\text { na Bahia }\end{array}$ & $\begin{array}{l}\text { Perché il samba è venuto } \\
\text { da Bahia }\end{array}$ \\
\hline Calque & $\begin{array}{l}\text { Na linha direta de Xangô, } \\
\text { saravá! }\end{array}$ & $\begin{array}{l}\text { Diretto discendente del } \\
\text { re Changò, saravà! }\end{array}$ \\
\hline
\end{tabular}




\begin{tabular}{|c|c|c|}
\hline Literal translation & Tristeza não tem fim & Tristezza non ha fine \\
\hline Transposition & O este é meu norte & Mio nord è l'est \\
\hline Explicitation & $\begin{array}{l}\text { E se hoje ele é branco na po- } \\
\text { esia }\end{array}$ & $\begin{array}{l}\text { E se è bianco di pelle in } \\
\text { poesia }\end{array}$ \\
\hline Implicitation & $\begin{array}{l}\text { A bênção a vocês, eu lhes } \\
\text { bendigo! }\end{array}$ & Io li benedico! \\
\hline Modulation & $\begin{array}{l}\text { É assim como a luz no cora- } \\
\text { cão }\end{array}$ & $\begin{array}{l}\text { È così come un sole } \\
\text { dentro il cuore }\end{array}$ \\
\hline Adaptation & $\begin{array}{l}\text { Há um frenesi de dar ba- } \\
\text { nana }\end{array}$ & $\begin{array}{l}\text { C'è un'aria di "ma che } \\
\text { 'mme frega" }\end{array}$ \\
\hline Addition & $\begin{array}{l}\text { Todas as mulheres estão } \\
\text { atentas }\end{array}$ & $\begin{array}{l}\text { Tutte le mogli stanno } \\
\text { bene attente }\end{array}$ \\
\hline
\end{tabular}

Aubert (1998a, p. 110) divides his modalities into two main groups: direct translation and indirect translation. The first covers those cases in which the translator did not make significant changes in the form and meaning of the source text (Transcription, Loan, Calque, Literal translation, and Transposition). The second, also known as oblique translation (Camargo 2004, p. 8), contains the modalities that alter the content of the source text significantly (Explicitation, Implicitation, Modulation, Adaptation, and Intersemiotic Translation). All the modalities can be applied separately in a pure state, or together in a hybrid way, as defined by Aubert (1998b, p. 139).

\section{Methodology}

The song texts in Brazilian Portuguese were collected from the books Antologia Poética (Moraes 1992), Livro de Sonetos (Moraes 2009), and from Vinicius de Moraes' official website (Extra Poetry 1999). The translated texts into Italian were taken from the CD booklet of La Musica, Amico, è l'Arte dell'Incontro (2005). All the analyzed songs are indicated in the following table: 
Table 3: Analyzed Poems and Songs

\begin{tabular}{|c|c|c|c|}
\hline Track & Portuguese Title & Italian Title & $\begin{array}{l}\text { Transla- } \\
\text { tor }\end{array}$ \\
\hline 1 & Samba da benção & Samba delle benedizioni & \multirow{6}{*}{$\begin{array}{l}\text { Sergio } \\
\text { Bardotti }\end{array}$} \\
\hline 2 & O que tinha de ser & Perché & \\
\hline 3 & Poema dos olhos da amada & Poema degli occhi & \\
\hline 4 & A casa & La casa & \\
\hline 5 & Rancho das flores & La marcia dei fiori & \\
\hline 6 & Se todos fossem iguais a você & $\begin{array}{l}\text { Se tutti fossero uguali a } \\
\text { te }\end{array}$ & \\
\hline
\end{tabular}

The source texts were aligned with the target texts to enable the analysis of the translation process according to the translation modalities (e.g., ordering and omissions). The analyzed verses contain a brief description of the translation modalities found. Also, we collected, accounted, and listed the results in a table presented in the analysis section.

As an example of the methodology used in this study, the following table demonstrates how the songs were analyzed: 
Table 4: Example of Source and Target Text Analysis

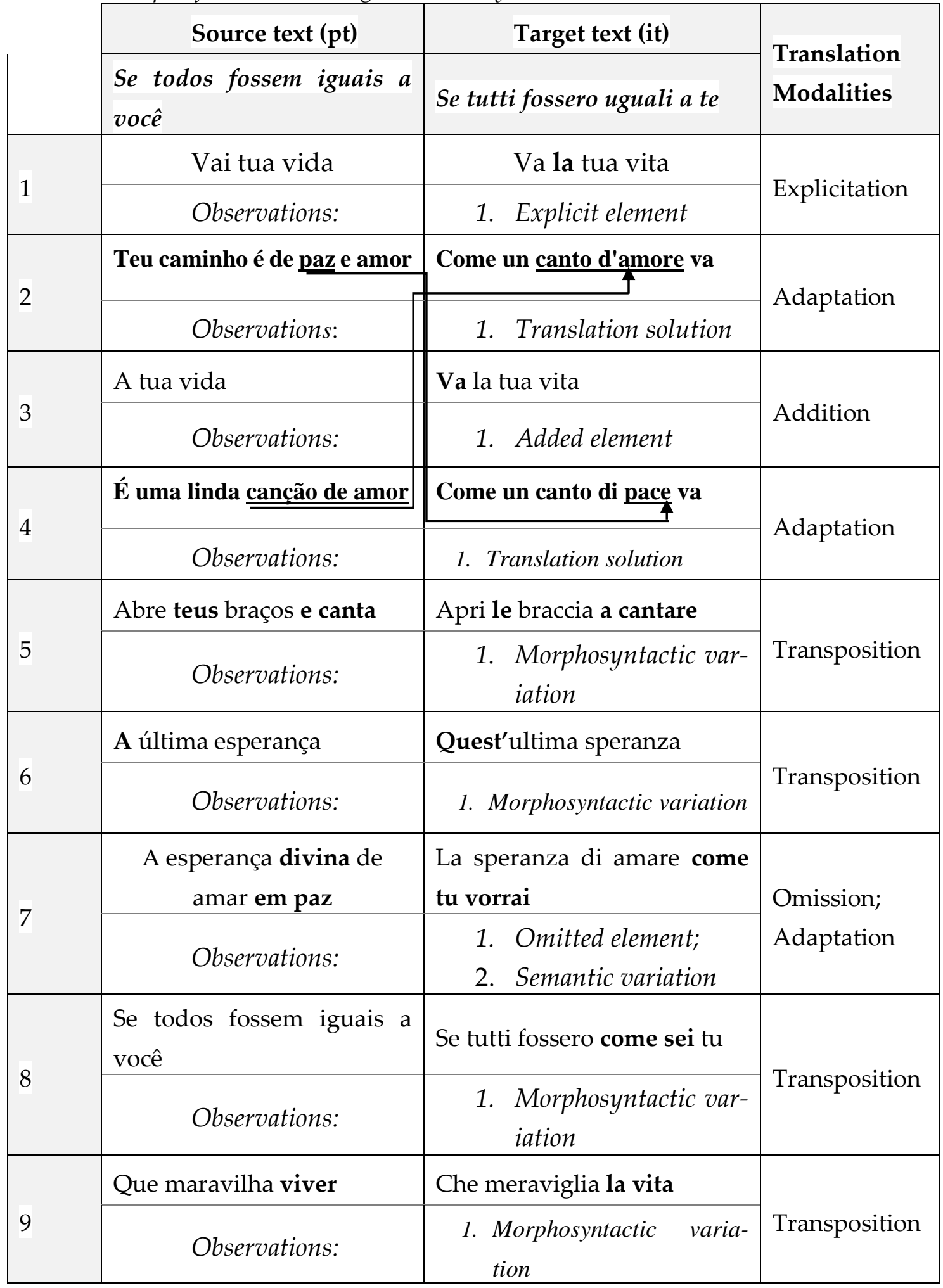




\begin{tabular}{|c|c|c|c|}
\hline \multirow{2}{*}{10} & Uma canção pelo ar & Una canzone nell'aria & \multirow{2}{*}{ Transposition } \\
\hline & Observations: & 1. Morphosyntactic variation & \\
\hline \multirow[b]{2}{*}{11} & Uma mulher a cantar & Per una donna che canta & \multirow{2}{*}{$\begin{array}{l}\text { Addition; } \\
\text { Transposition }\end{array}$} \\
\hline & Observations: & $\begin{array}{l}\text { 1. Added element; } \\
\text { 2. Morphosyntactic variation }\end{array}$ & \\
\hline \multirow[b]{2}{*}{12} & Uma cidade a cantar & La città intera che canta & \multirow[b]{2}{*}{$\begin{array}{l}\text { Transposition; } \\
\text { Addition }\end{array}$} \\
\hline & Observations: & $\begin{array}{l}\text { 1. Morphosyntactic varia- } \\
\text { tion; } \\
\text { 2. Added element }\end{array}$ & \\
\hline \multirow[b]{2}{*}{13} & A sorrir, a cantar, a pedir & La città che sorride & \multirow[b]{2}{*}{$\begin{array}{l}\text { Transposition; } \\
\text { Omission; } \\
\text { Explicitation }\end{array}$} \\
\hline & Observations: & $\begin{array}{l}\text { 1. Morphosyntactic varia- } \\
\text { tion; } \\
\text { 2. Omitted elements; } \\
\text { 3. Explicit element }\end{array}$ & \\
\hline \multirow[b]{2}{*}{14} & A beleza de amar & E ritrova la gioia di amare & \multirow{2}{*}{$\begin{array}{l}\text { Addition; } \\
\text { Adaptation }\end{array}$} \\
\hline & Observations: & $\begin{array}{l}\text { 1. Added element; } \\
\text { 2. Translation solution }\end{array}$ & \\
\hline \multirow[t]{2}{*}{15} & $\begin{array}{l}\text { Como o sol, como a flor, } \\
\text { como a luz }\end{array}$ & $\begin{array}{l}\text { Questo cielo, questo sole, } \\
\text { questo mare }\end{array}$ & \multirow[t]{2}{*}{ Adaptation } \\
\hline & Observations: & 1. Semantic variation & \\
\hline \multirow{2}{*}{16} & Amar sem mentir, nem so- & Amare la vita com'è & \multirow{2}{*}{--} \\
\hline & Observations: & 1. Semantic variation & \\
\hline \multirow[b]{2}{*}{17} & Existiria a verdade & Esisterebbe per tutti & \multirow{2}{*}{$\begin{array}{l}\text { Omission; } \\
\text { Addition }\end{array}$} \\
\hline & Observations: & $\begin{array}{l}\text { 1. Omitted elements; } \\
\text { 2. Element added }\end{array}$ & \\
\hline \multirow[b]{2}{*}{18} & Verdade que ninguém vê & La verità che non c'è & \multirow[b]{2}{*}{ Adaptation } \\
\hline & Observations: & $\begin{array}{l}\text { 1. Explicit element } \\
\text { 2. Translation solution }\end{array}$ & \\
\hline 19 & $\begin{array}{l}\text { Se todos fossem no mundo } \\
\text { iguais a você }\end{array}$ & $\begin{array}{l}\text { Se tutti fossero al mondo } \\
\text { uguali a te }\end{array}$ & $\begin{array}{l}\text { Literal trans- } \\
\text { lation }\end{array}$ \\
\hline
\end{tabular}




\section{Analysis}

The same methodology was applied to all six songs and their translations.

Table 5 describes the abbreviations used in the results table and the graph. Table 6 presents the results of this analysis and also provides the sum of all modalities found in each translated song.

Table 5: Abbreviations Used in the Results Table

\begin{tabular}{|l|l|l|c|}
\hline \multicolumn{3}{|c|}{ Translation Modalities } \\
\hline M1 & Omission & M8 & Implicitation \\
M3 & Transcription & M9 & Modulation \\
M4 & Loan & M10 & Adaptation \\
M5 & Calque & M11 & Intersemiotic translation \\
M6 & Literal translation & $\mathbf{M 1 2}$ & Error \\
M7 & Transposition & $\mathbf{M 1 3}$ & Correction \\
\hline
\end{tabular}

\begin{tabular}{|c|c|c|}
\hline \multicolumn{3}{|c|}{ Source and Target Texts } \\
\hline 1 & Samba da benção & Samba delle benedizioni \\
\hline 2 & O que tinha de ser & Perché \\
\hline 3 & $\begin{array}{l}\text { Poema dos olhos da } \\
\text { amada }\end{array}$ & Poema degli occhi \\
\hline 4 & A casa & La casa \\
\hline 5 & Rancho das flores & La marcia dei fiori \\
\hline 6 & $\begin{array}{l}\text { Se todos fossem iguais a } \\
\text { você }\end{array}$ & Se tutti fossero uguali a te \\
\hline
\end{tabular}


Table 6: Translation Modalities Occurrences

\begin{tabular}{|c|c|c|c|c|c|c|c|}
\hline \multicolumn{2}{|r|}{ T1 } & $\mathbf{T} 2$ & T3 & T4 & T5 & T6 & TOTAL 1 \\
\hline M1 & 40 & 1 & 11 & 2 & 12 & 3 & 69 \\
\hline M2 & - & - & - & - & - & - & - \\
\hline M3 & 15 & - & - & - & - & - & 15 \\
\hline M4 & 1 & - & - & - & - & - & 1 \\
\hline M5 & 12 & - & 9 & 2 & - & 1 & 24 \\
\hline M6 & 50 & 5 & 8 & 3 & 13 & 7 & 86 \\
\hline M7 & 6 & 1 & 1 & 2 & - & 2 & 12 \\
\hline M8 & 1 & - & 1 & 1 & 1 & - & 4 \\
\hline M9 & 15 & - & 3 & 5 & 2 & 1 & 26 \\
\hline M10 & 8 & 4 & 5 & 7 & 23 & 6 & 53 \\
\hline M11 & - & - & - & - & - & - & - \\
\hline M12 & - & - & - & - & - & - & - \\
\hline M13 & - & - & - & - & - & - & - \\
\hline M14 & 13 & - & 2 & - & 2 & 5 & 22 \\
\hline \multicolumn{2}{|c|}{ TOTAL 2161} & 11 & 40 & 22 & 53 & 25 & \\
\hline
\end{tabular}

The following graph illustrates the results shown in the previous table: 


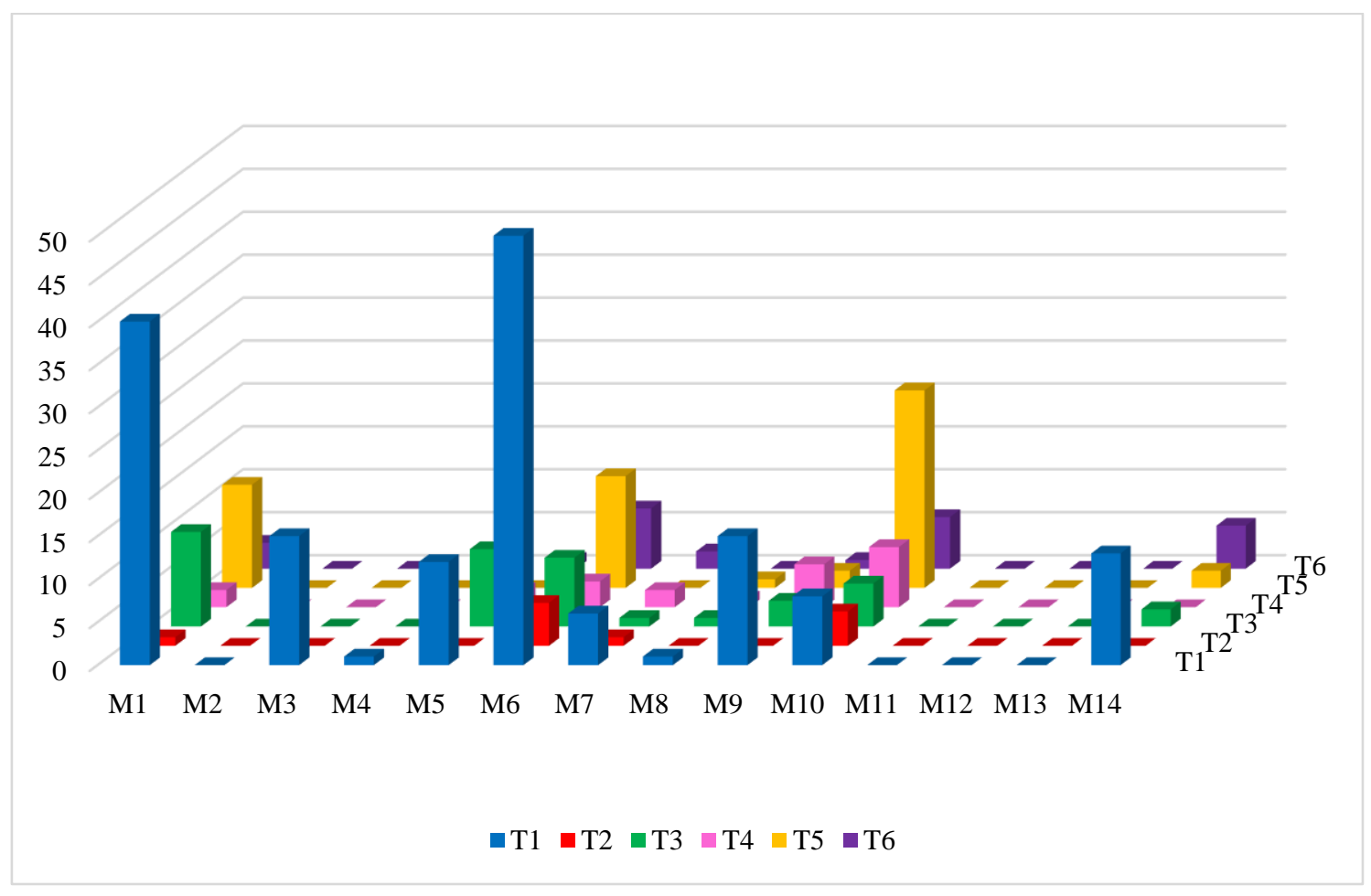

Figure 1. Occurrence of translation modalities in the translation.

Transposition (i.e., the translator changes the structure but still preserves the meaning) was the most used modality, especially in the translated song "Samba delle Benedizioni" (T1). This song contains the most significant number of occurrences regarding modalities in general, which is interesting since this is the most culturally marked song from the album. In its first part, chosen as the first track of the album, Vinicius de Moraes talks about samba, candomblé, and Brazilian artists. In the second part, which is the last track of the album, he mentions Brazilian artists again and thanks Ungaretti, Endrigo and the children's choir. The translated song "La Marcia dei Fiori" presented the second most significant number of Transposition. The length of both songs might explain the significant number of occurrences in general.

The second most used modality was Omission (i.e., the translator omits part of the source text and its information). Bardotti omitted words in some songs to keep the target text singable, as indicated in the following example:

(Br. Pt.) A benção, maestro Antonio Carlos Jobim 
(It.) Benedizione, Antonio Carlos Jobim

Bardotti also omitted the verses of some songs. For instance, the third stanza from the song "Poema dos Olhos da Amada" was omitted from the target text "Poema degli Occhi." He probably intended to keep songs short (considering they would also be recorded on vinyl).

Adaptation (i.e., the target segment is only partially equivalent to the source segment) was the third most used modality applied to convey similar meanings in the target verses, even though the meaning of the source verses was slightly different. As an example, we present the following verse from the song "Se Todos fossem Iguais a Você" and its translation:

\section{(Br. Pt.) Verdade que ninguém vê}

(It.) La verità che non c'è

Bardotti had to adapt the verse to keep the song structure intact and convey a partially different meaning. The source verse mentions the truth that nobody sees, while the target verse mentions the truth that does not exist.

Loan (i.e., the translator reproduces a segment of the source text ipsis litteris in the translation) and Modulation (i.e., a translated segment undergoes an evident semantic change but still retains the general meaning of the source segment) are the fourth most used modalities. We indicate below a Loan example taken from the song "Samba delle Benedizioni." Bardotti opted to reproduce the name Oxum precisely as it is written in the source text:

\section{(Br. Pt.) Lindo como a pele macia de Oxum}

(It.) Bello e liscio come la pelle della dea Oxum

The following verse was taken from the translated song "La Marcia dei Fiori" to demonstrate how Modulation changed the semantic structure while preserving the meaning of the source verses: 
(Br. Pt.) Não há mais formosa

(It.) $\grave{E}$ meravigliosa

The source verse means there is nothing more beautiful, while the target verse means it is wonderful. Despite being slightly different, the meaning is almost the same.

Literal Translation (i.e., each segment of the source text can be considered equivalent to the segments of the target text) was the fifth most used modality. The verses maintained the same morphosyntactic structure and preserved the meaning of the source verses, as indicated in the example taken from the song "Se Tutti fossero Uguali a Te":

(Br. Pt.) Se todos fossem no mundo iguais a você

(It.) Se tutti fossero al mondo uguali a te

Bardotti seemed to use Addition (i.e., the translator adds segments in the target text that are not present in the source text) to adapt the verses to the music structure, as indicated in the example taken from the song "Se Tutti fossero Uguali a Te":

(Br. Pt.) A beleza de amar

(It.) E ritrova la gioia di amare

There were also Explicitations (i.e., the translator explains words and concepts from the source text in the target text). Most of them occurred in the translated song "Samba delle Benedizioni" (T1), in the source verses containing explicit or implicit segments. Bardotti also added new elements and information, as indicated in the following example:

(Br. Pt.) Na linha direta de Xangô, saravá!

(It.) Diretto discendente del re Changò, saravà! Cioè: salve! 
In this verse, Bardotti chose to explain the term saravá using a roughly equivalent Italian word. Bardotti also mentions in his translation that Xangô is a king, although this information was not explicit in the source text.

Implicitation (i.e., the translator omits words and concepts from the source text) was used when a segment was already mentioned before, allowing the insertion of longer verses with new information, as indicated in the example taken from the song "La Casa." Bardotti did not mention the house in the target verse anymore because it would not fit into the music structure. Furthermore, the house was already mentioned before in the song:

(Br. Pt.) Porque na casa / Não tinha chão

(It.) Perché / non c'era il pavimento

Calque (i.e., the translator takes words from the original text, but modify them graphically or morphologically) had only one occurrence in the translated song "Samba delle Benedizioni," as an attempt to write the name Xangô according to its pronunciation in Brazilian Portuguese:

(Br. Pt.) Na linha direta de Xangô, saravá!

(It.) Diretto discendente del re Changò, saravà! Cioè: salve!

Different from the Loan applied in the translation of the name Oxum, Bardotti opted to change the letter $\mathrm{X}$ to $\mathrm{CH}$, probably to indicate how to pronounce the $X$.

Transcription (i.e., textual elements present in both languages, such as symbols, digits, and other signs), Intersemiotic Translation (i.e., the translator describes the symbols and figures included in the source text), Error (i.e., the target text conveys a different meaning from the source text due to translator's mistakes) and Correction (i.e., the translator corrects linguistic errors and inadequacies in the source text) did not occur in the analyzed translated texts. Also, there is no evidence of Semiotic Translation. 
Bardotti utterly changed the meaning of fifteen verses in his translation. The following example indicates how the meaning changed from the source to the target text:

(Br. Pt.) Porque foste em minh'alma / Como um amanhecer

(It.) Perché ho trovato calma / Soltanto insieme a te

We could not classify them according to the translation modalities because there was no modality equivalent to the changes made.

\section{Conclusion}

This study aimed to analyze the translation process of six Brazilian songs composed by Vinicius de Moraes. We based the analysis on Aubert's (1998) translation modalities in order to identify the strategies applied by Sergio Bardotti during the translation of the songs into Italian.

Vinicius de Moraes attended the recording sessions and also translated some verses. The composer's presence and his active participation make La Vita, Amico, è l'Arte dell'Incontro an experimental and innovative project that mixes songs, recited poetry, and short instrumental tracks.

Translation modalities demonstrated to be a useful method to analyze the procedures applied by the translator, as it allowed us to identify the types and levels of adaptation and changes applied during the translation of the song texts. Nevertheless, we could not analyze the completely changed verses in the target text with the help of translation modalities because there is no modality proposed by Aubert that deals with that level of modification. Scholars and translators usually do not consider completely changed verses (which is a usual practice in song translation) as translation, which might explain why there is no modality related to these changes. Probably, Aubert did not expect to have his translation modalities applied to song translation.

In future studies, it would also be useful to describe the fundamental principles of music regarding the composition and structure of a song, as done by Hayes and Kaun (1996), and Buhler (2017) so that translators can better understand the requirements and peculiarities of song translation. 


\section{References}

AUBERT, F. H. Modalidades de tradução: teoria e resultados. TradTerm, 5

(1), 99-128, 1998a. Available at https://doi.org/10.11606/issn.23179511.tradterm.1998.49775

Translation modalities: theory and practical results. TradTerm,

5 (1), 129-157, 1998b. Available at https://doi.org/10.11606/issn.23179511.tradterm.1998.49775

BARDOTTI, S., Moraes, V., \& UNGARETTI, G. La vita, amico, è l'arte dell'incontro [CD]. Milano: Warner Music Italia Srl., 2005.

BUHLER, F. The pitfalls of musical translation. TranscUlturAl: A Journal of Translation and Cultural Studies, 9 (1), 7-26, 2017. Available at https://doi.org/10.21992/T94329

CAMARGO, D. C. Uma análise de semelhanças e diferenças na tradução de textos técnicos, jornalísticos e literários. Delta, 20 (1), 1-25, 2004. Available at http://dx.doi.org/10.1590/S0102-44502004000100001

CAMPOS, A. Balanço da bossa e outras bossas. São Paulo: Perspectiva, 1993.

EXTRA POETRY. Vinicius de Moraes, 1999. Available at https://www.viniciusdemoraes.com.br/pt-br/poesia/poesias-avulsas

FRANZON, J. Choices in song translation: singability in print, subtitles and sung performance. The Translator, 14 (2), 373-399, 2008. Available at https://doi.org/10.1080/13556509.2008.10799263

GRITSENKO, E., \& ALESHINSKAYA, E. Translation of song lyrics as structure-related expressive device. Procedia - Social and Behavioral Sciences, 231, 165-172, 2016. Available at https://doi.org/10.1016/j.sbspro.2016.09.087

HAYES, B., \& KAUN, A. The role of phonological phrasing in sung and chanted verse. The Linguistic Review, 13 (3-4), 243-303, 1996. Available at https://doi.org/10.1515/tlir.1996.13.3-4.243

LOW, P. Singable translations of songs. Perspectives: Studies in Translatol-

ogy, 11 (2), 87-103, 2003. Available at https://doi.org/10.1080/0907676X.2003.9961466 
The Pentathlon Approach to translating songs. In GORLÉE, D. L. (Ed.), Song and Significance: Virtues and Vices of Vocal Translation. Amsterdam /New York: Rodopi, 2005, pp. 185-212.

Translating songs that rhyme. Perspectives: Studies in Transla-

tology, $16 \quad(1-2), \quad 1-20, \quad 2008 . \quad$ Available at
https://doi.org/10.1080/13670050802364437

MORAES, V. Antologia poética. São Paulo: Companhia das Letras, 1992.

Livro de sonetos. São Paulo: Companhia das Letras, 2009.

NAVES, S. C. Da bossa nova à tropicália. Rio de Janeiro: Jorge Zahar Editor, 2001.

PAJDZIŃSKA, A. The Linguistic Worldview and Literature. In A. GŁAZ, D.; DANAHER, S. \& P. Łozowski (Eds.), The Linguistic Worldview: Ethnolinguistics, Cognition, and Culture (pp. 41-59). London: Versita, 2013.

SUSAM-SARAJEVA, Ş. Translation and music. The Translator, 14 (2), 187200, 2008. Available at https://doi.org/10.1080/13556509.2008.10799255

TAGNIN, S. E. O. O jeito que a gente diz. São Paulo: Disal, 2005.

TATIT, L. O século da canção. São Paulo: Ateliê Editorial, 2004.

VINAY, J.-P., \& DARBELNET, J. Stylistique comparée du français et de l'anglais: méthode de traduction. Paris: Didier, 1958.

\begin{abstract}
The aim of this article is to analyze the translation of six songs composed by Vinicius de Moraes and translated into Italian by Sergio Bardotti. We analyzed the translated songs according to the thirteen translation modalities proposed by Aubert (1998). The results indicated how the translator fitted the texts into the melody and harmony of the songs. This preliminary study hopes to demonstrate how the translation process occurs when the target text must fit into a pre-established music structure.

Keywords: Bossa Nova; Music; Song Translation; Translation modalities.

\section{Resumo}

Este trabalho teve por objetivo analisar a tradução em italiano de seis canções de Vinicius de Moraes. As traduções, feitas por Sergio Bardotti, foram analisadas conforme as treze Modalidades de Tradução propostas por Aubert
\end{abstract}


(1998). Os resultados demonstram os passos seguidos pelo tradutor para inserir os textos na melodia e harmonia das canções. Espera-se demonstrar, ainda que de forma sucinta, como o processo tradutório é desenvolvido quando o texto deve encaixar-se a uma estrutura musical pré-estabelecida.

Palavras-chave: Bossa Nova; Música; Tradução de canção; Modalidades de tradução. 